\title{
Analysis of Quality of Drinking Water Taken from Different Academic Institutes of District Vehari, Pakistan
}

\author{
M. Fazal-ur-Rehman \\ Chemistry Department, University of Education, Lahore-Vehari Campus, Punjab, Pakistan
}

\begin{abstract}
Five samples of drinking water (DW) were taken from five different academic institutes of District Vehari, Pakistan which are; Sample-1 from University of Education Vehari Campus; Sample-2 from Government Post Graduate College for Women Vehari; Sample-3 from Government Post Graduate College for Boys Vehari; Sample-4 from COMSATS Institute of Information Technology Vehari Campus and Sample-5 from BZU Vehari Campus. The analysis was qualitative as well as quantitative to determine the quality of DW, which is based on the determination of physico-chemical characteristics of DW samples. These physico-chemical characteristics are; $\mathrm{pH}$, temperature, turbidity, alkalinity, total hardness, chloride ion estimation, color and taste. Different chemical tests and techniques were applied to determine the water quality. After that, the results obtained from these experiments indicated that Sample-2 is very polluted with large amounts of salts which cause its hardness and made it unfit for drinking purposes, because this hardness causes health diseases in humans. The Sample-3 contains large amounts of chloride ions which hardened it, as its temperature is also low. Except Sample-3, all other four samples are not much polluted and are fit for drinking. So, author recommended leaving the use of Sample-3 of water of Government Post Graduate College for Boys Vehari.
\end{abstract}

Keywords: Drinking water; Reverse boring; Pollutant contamination; Turbidity; Hardness

\section{Introduction}

Healthy and safe water means healthy and safe life from diseases, because water is the main concern and elixir of life of humans and other livings. If you want a healthy and safe life from diseases, then you should have to use purified, safe water [1]. Water is mostly distributed in wide ranges and is the most abundant chemical in nature. The fact is that our planet earth is covered with water, approximately 1400 million billion liters [2]. But not all the water is safe and potable. Rather, $97 \%$ of total water of earth planet is sea water which is not safe even for washing purposes. Rest of 3\% water, is freshwater [3]. From this 3\% freshwater, $2 \%$ is in polar ice caps and glaciers, while only $1 \%$ water is found for portable uses. But now a day, even this only $1 \%$ water is not safe for drinking due to contamination of different pollutants, waste products. These pollutants are carbonates, bicarbonates, sulfates and chlorides of calcium and magnesium [4]. These pollutants are mixed in ground water and made it unfit for drinking.

For Centuries, human has started to dispose of the waste products of industries. These waste products are disposed off by reverse boring, burning, and placing within streams and by storing them into ground or dumping them on the ground [5]. Reverse boring is the method in which the waste products especially chemicals are disposed of in depth of earth by pipes. These waste products also contain surface run off of chemical industries. All these waste products may disrupt the quality of DW [6].

One of the main sources of contamination is the storage of these waste products in mines and pits. The water soluble substances and chemicals are spilled, disrupted and spread on the ground, may mixed with underground DW and make it unfit for drinking purposes [7].

Due to increased human population, industrialization, use of fertilizers in agriculture and man-made activity, natural aquatic resources are causing heavy and varied pollution in aquatic environment leading to water quality and depletion of aquatic biota. It is therefore necessary that the quality of DW should be checked at regular time interval because due to use of contaminated DW, human population suffers from a variety of water-borne diseases. It is difficult to understand the biological phenomena fully because the chemistry of water reveals much about the metabolism of the ecosystem and explain the general hydro- biological relationship. The physico-chemical parameters of water and the dependence of all life process of these factors make it desirable to take as an environment [8].

In present study involves the analysis of water quality in terms of physico-chemical parameters.

\section{Experimental}

\section{Materials/Chemicals}

Five samples of DW were taken from five different education institutes of District Vehari, Pakistan which are; Sample-1 from University of Education Vehari Campus; Sample-2 from Government College for Women Vehari; Sample-3 from Government College for boys Vehari; Sample-4 from COMSATS Institute of Information Technology Vehari Campus and Sample-5 from BZU Vehari Campus (Table 1). The analysis was qualitative as well as quantitative to determine the quality of DW, which is based on the determination of physico-chemical characteristics of DW samples. These physico-chemical characteristics are $\mathrm{pH}$, temperature, turbidity, alkalinity, total hardness, chloride ion estimation, color and taste.

\begin{tabular}{|c|c|c|}
\hline No. & Sample & Source \\
\hline 1 & Sample-1 & University of Education, Vehari Campus \\
\hline 2 & Sample-2 & Govt. College for Women Vehari \\
\hline 3 & Sample-3 & Govt. College for Boys Vehari \\
\hline 4 & Sample-4 & COMSATS IIT Vehari Campus \\
\hline 5 & Sample-5 & BZU Sub Campus Vehari \\
\hline
\end{tabular}

Table 1: Selection of five different samples of DW.

*Corresponding author: M. Fazal-ur-Rehman, Chemistry Department, University of Education, Lahore-Vehari Campus, Punjab, Pakistan, Tel: +923056576561. E-mail: fazalurrehman517@gmail.com

Received August 07, 2017; Accepted August 11, 2017; Published August 18 2017

Citation: M. Fazal-ur-Rehman (2017) Analysis of Quality of Drinking Water Taken from Different Academic Institutes of District Vehari, Pakistan. J Environ Anal Chem 4: 211. doi:10.41722380-2391.1000211

Copyright: ( 2017 M. Fazal-ur-Rehman. This is an open-access article distributed under the terms of the Creative Commons Attribution License, which permits unrestricted use, distribution, and reproduction in any medium, provided the original author and source are credited. 
To determine the hardness of samples, EDTA solution is used as indicator. To determine the alkalinity, standard $\mathrm{H}_{2} \mathrm{SO}_{4}$ is used. To measure the quantity of chloride, Erichrome Black-T indicator is used. For determination of turbidity, Formazine (Normal standard) is used as indicator solution.

\section{pH measurement}

$\mathrm{pH}$ of the all five samples was measured at the time of their collection at the spot. $\mathrm{pH}$ was measured by portable battery operated $\mathrm{pH}$-meter Model MP220. The standard value for $\mathrm{pH}$ lies between 4.0 to 7.0. The $\mathrm{pH}$ of each sample was noted from the $\mathrm{pH}$ meter when the appeared value remained constant for 60 seconds. After this measurement, the electrodes of $\mathrm{pH}$ meter were washed with distilled water and cleaned by tissue paper.

\section{Temperature}

The thermometer is inserted into beakers of all five samples at the time of their collection and noted their temperature. The values of temperature for all the samples were noted when the values appeared for 60 seconds. After temperature determination, the thermometer is washed distilled water and then cleaned with tissue paper.

\section{Total hardness determination}

$1 \mathrm{~mL}$ of Buffer solution was added into $50 \mathrm{~mL}$ water of each sample addition with 1-2 drops of indicator. This prepared solution is titrated against EDTA solution. The pink red color of solution was turned into blue, showing the completion of titration. The hardness was calculated by following formula:

Total Hardness=[EDTA Solution $(\mathrm{mL}) \times \mathrm{MI}$ of sample $(\mathrm{mg} / \mathrm{L}] 1000$

\section{Alkalinity}

Alkalinity means the measurement of $\mathrm{OH}^{-}$and $\mathrm{CO}_{3}^{-2}$ ionic content present in water sample. Samples were titrated with standard $\mathrm{H}_{2} \mathrm{SO}_{4}$ along with indicator. Pink Color of samples disappeared, indicating the completion of titration.

\section{Chloride estimation}

The test for chloride estimation in water is argentometric titration. In this test, $\mathrm{AgNO}_{3}$ is added into water, while 2-3 drops of indicator Erichrome Black-T (EBT) is added into prepared sample. The dark pink color turned into milky colored precipitates of $\mathrm{AgCl}$.

\section{Turbidity}

A turbidimeter (Nephelometer) was used in this test to determine the turbidity of water samples while Formazine was used to standardize the Nephelometer.

\section{Total Dissolved Solids (TDS)}

Solids refer to the matter dissolved or suspended in water which may alter the quality of DW severely in different ways. For DW, limit of TDS is $500 \mathrm{mg}$. TDS of samples was measured by pre-calibrated conductivity meter. Measurements were taken at room temperature. The samples were transferred into beaker of $50 \mathrm{~mL}$, electrodes were dipped into samples, after that button of conductivity meter was pressed and TDS values for each of five samples were noted.

\section{Conductivity}

Conductivity is also measured by conductivity meter. Samples were filled in beakers $(50 \mathrm{~mL})$ and electrodes of conductivity meter were dipped in. The constant appeared values for each sample were noted.

\section{Results and Discussion}

Following results were obtained after all tests.

\section{pH}

After the $\mathrm{pH}$ determination of all five samples, we noted that the $\mathrm{pH}$ lies between 4.0 to 9.0. Sample-3 has maximum $\mathrm{pH}$ Value of 8.86, showing basic nature of water, while the minimum value obtained is 7.29 which is of Sample-1, showing the almost neutral nature of water (Table 2; Figure 1).

\begin{tabular}{|c|c|c|c|c|}
\hline No. & Sample & Source & Temperature ( $\left.{ }^{\circ} \mathbf{C}\right)$ \\
\hline 1 & Sample-1 & University of Education Vehari Campus & 26 \\
\hline 2 & Sample-2 & Govt. College for Women Vehari & 22 \\
\hline 3 & Sample-3 & Govt. College for Boys Vehari & 7.29 \\
\hline 4 & Sample-4 & COMSATS IIT Vehari Campus & 7.39 \\
\hline 5 & Sample-5 & BZU Sub Campus Vehari & 24 & 7.86 \\
\hline
\end{tabular}

Table 2: Temperature, $\mathrm{pH}$ and TDS values of all five samples of DW.

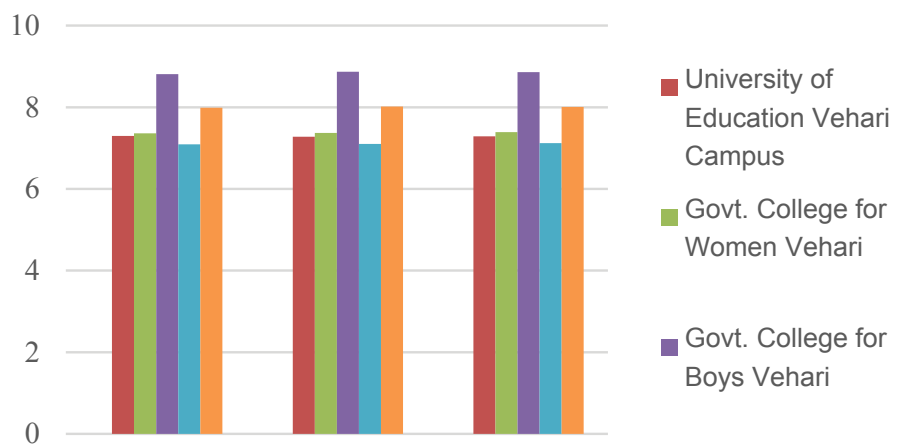

$\mathrm{pH}$ - Values

Figure 1: $\mathrm{pH}$ values of all five samples of DW. 


\section{Temperature}

The temperature is usually lies between $14^{\circ} \mathrm{C}$ to $28^{\circ} \mathrm{C}$. The Sample- 3 has very low temperature of $14^{\circ} \mathrm{C}$, while Sample-1 has very normal temperature of $26^{\circ} \mathrm{C}$ (Table 2; Figure 2). Normal temperature indicates that the water is potable.

\section{TDS}

The results showed that Sample-1 has TDS value of 550 NTU, Sample-2 has 595 NTU, Sample-3 has 875 NTU, Sample-4 has 620 NTU and Sample-5 has 670 NTU (Table 2; Figure 3). Sample-3 has maximum TDS value indicating that the water of Government College for Boys Vehari is unfit for drinking purposes.

\section{Alkalinity}

The results showed that Sample-1 has $560 \mathrm{mg} / \mathrm{L}$ alkalinity, Sample-2 has $620 \mathrm{mg} / \mathrm{L}$, Sample-3 has $890 \mathrm{mg} / \mathrm{L}$, Sample-4 has 625 $\mathrm{mg} / \mathrm{L}$ and Sample-5 has $670 \mathrm{mg} / \mathrm{L}$ alkalinity values (Table 3; Figure 4).
The WHO reported that the suitable alkalinity for DW is $500 \mathrm{mg} / \mathrm{L}$. So by comparing this, Sample-3 has maximum value of $890 \mathrm{mg} / \mathrm{L}$ and Sample- 1 has $560 \mathrm{mg} / \mathrm{L}$ alkalinity, which indicated that Sample-3 is not potable.

\section{Total hardness (Calcium hardness)}

The resulted values of total hardness of all five samples were: 75 $\mathrm{mg} / \mathrm{L}$ for Sample-1, $79 \mathrm{mg} / \mathrm{L}$ for Sample-2, $125 \mathrm{mg} / \mathrm{L}$ for Sample-3, 80 $\mathrm{mg} / \mathrm{L}$ for Sample- 4 and $87 \mathrm{mg} / \mathrm{L}$ for Sample-5 (Table 3; Figure 5). These results indicated that maximum value of total hardness is $125 \mathrm{mg} / \mathrm{L}$ for Sample-3, concluding that Sample-3 is not potable.

\section{Chloride hardness}

The results of all five samples were: Sample- 1 has $72 \mathrm{mg} / \mathrm{L}$, Sample- 2 has $77 \mathrm{mg} / \mathrm{L}$, Sample-3 has $135 \mathrm{mg} / \mathrm{L}$, Sample-4 has $85 \mathrm{mg} / \mathrm{L}$ and Sample- 5 has $97 \mathrm{mg} / \mathrm{L}$ of chloride ions amounts (Table 3; Figure 6). The maximum value of $135 \mathrm{mg} / \mathrm{L}$ indicates that Sample-3 is unfit for drinking.

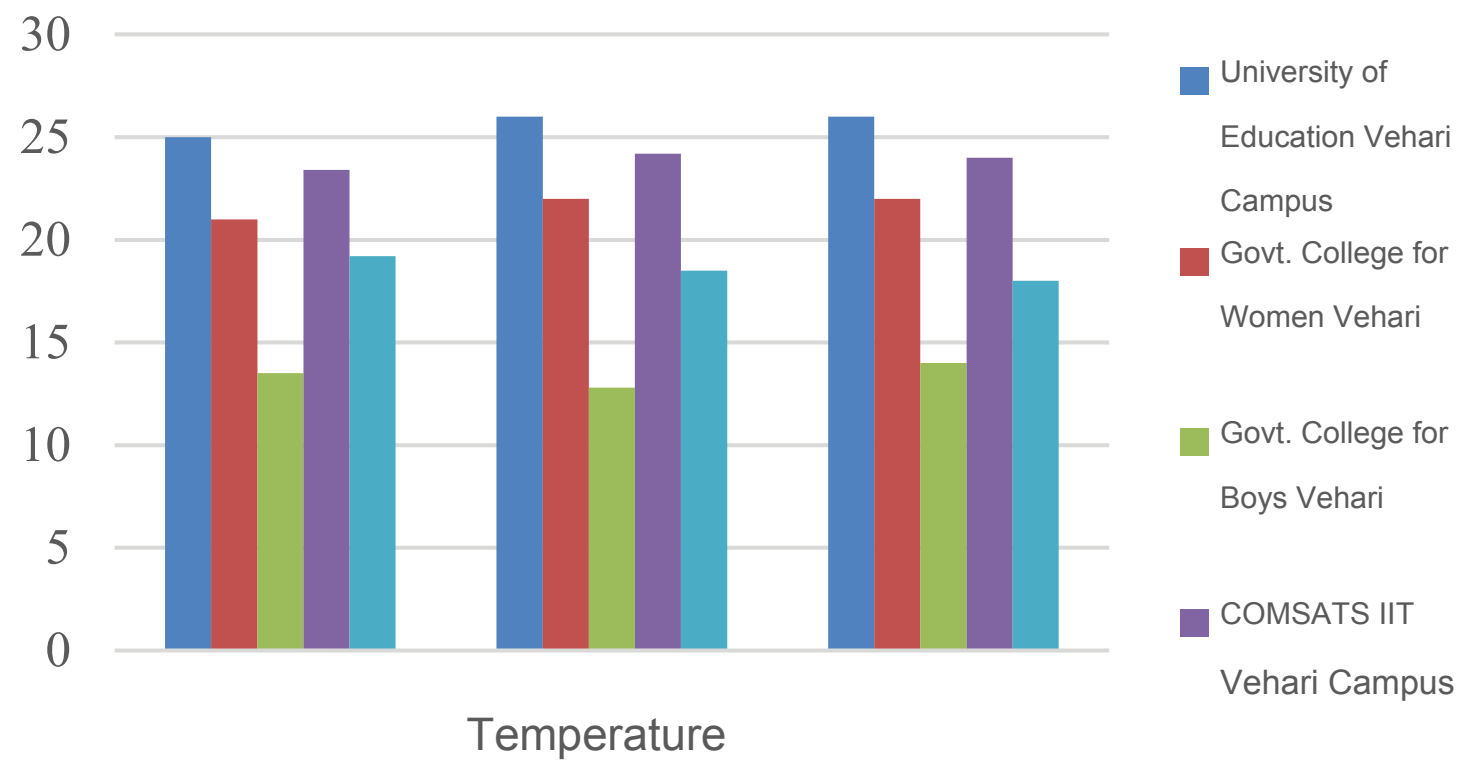

Figure 2: Temperature of all five samples of DW.

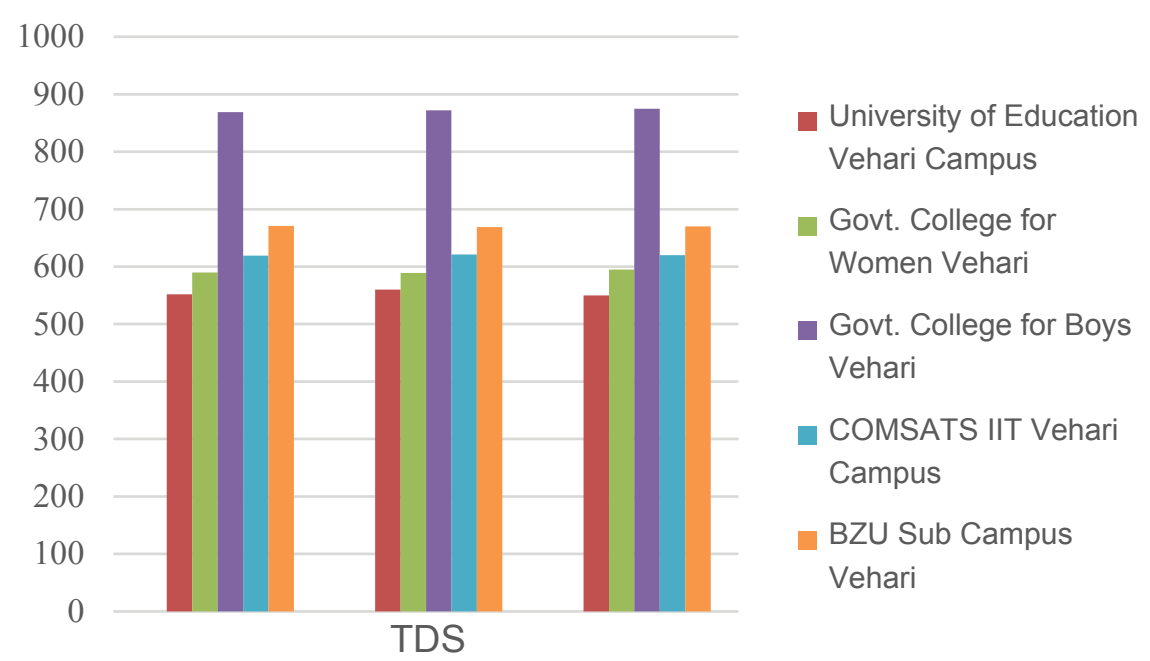

Figure 3: TDS values of all five samples of DW. 
Citation: M. Fazal-ur-Rehman (2017) Analysis of Quality of Drinking Water Taken from Different Academic Institutes of District Vehari, Pakistan. J Environ Anal Chem 4: 211. doi:10.41722380-2391.1000211

Page 4 of 6

\begin{tabular}{|c|c|c|c|c|c|}
\hline No. & Sample & Source & Calcium hardness (mg/L) & Chloride mg/L & Alkalinity mg/L \\
\hline 1 & Sample-1 & University of Education Vehari Campus & 75 & 72 \\
\hline 2 & Sample-2 & Govt. College for Women Vehari & 79 & 77 \\
\hline 3 & Sample-3 & Govt. College for Boys Vehari & 125 & 135 \\
\hline 4 & Sample-4 & COMSATS IIT Vehari Campus & 80 & 85 \\
\hline 5 & Sample-5 & BZU Sub Campus Vehari & 87 & 625 \\
\hline
\end{tabular}

Table 3: Calcium hardness, Chloride hardness and alkalinity of all five samples of DW.

\begin{tabular}{|c|c|c|c|}
\hline No. & Sample & Source & Conductance ( $\boldsymbol{\mu s} / \mathbf{c m})$ \\
\hline 1 & Sample-1 & University of Education Vehari Campus \\
\hline 2 & Sample-2 & Govt. College for Women Vehari \\
\hline 3 & Sample-3 & Govt. College for Boys Vehari \\
\hline 4 & Sample-4 & COMSATS IIT Vehari Campus \\
\hline 5 & Sample-5 & BZU Sub Campus Vehari \\
\hline
\end{tabular}

Table 4: Conductance values of all five samples of DW.

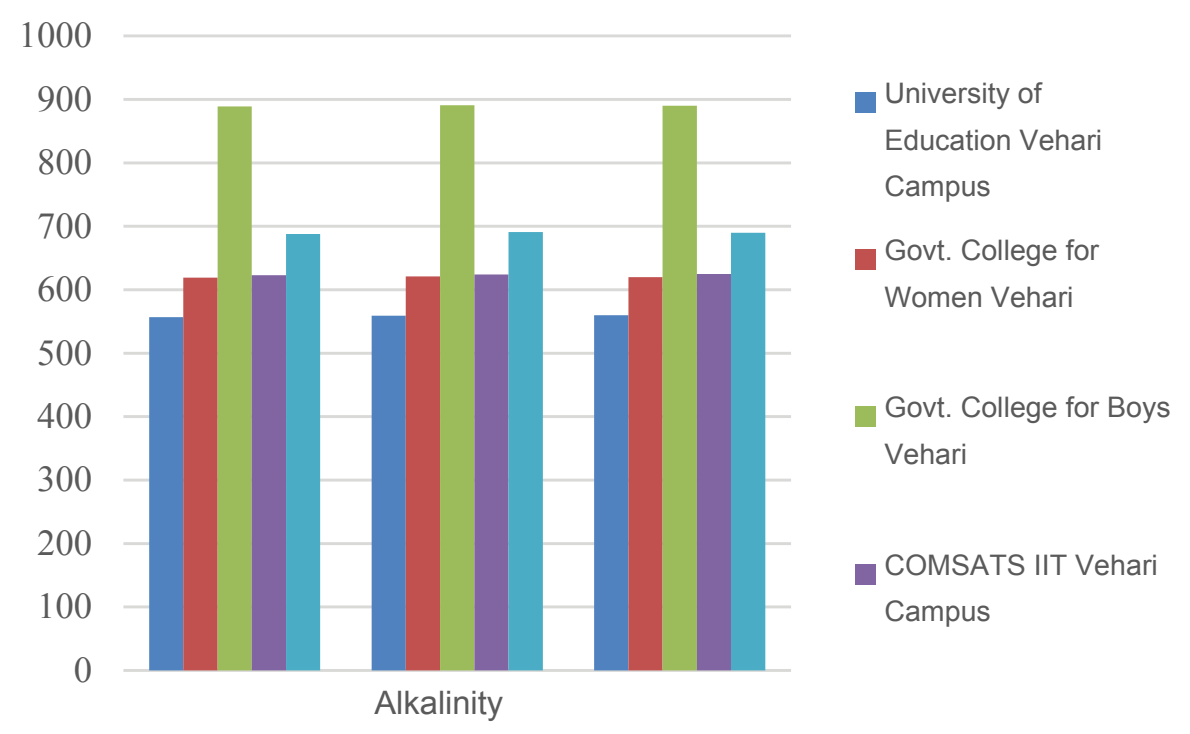

Figure 4: Alkalinity values of all samples of DW.

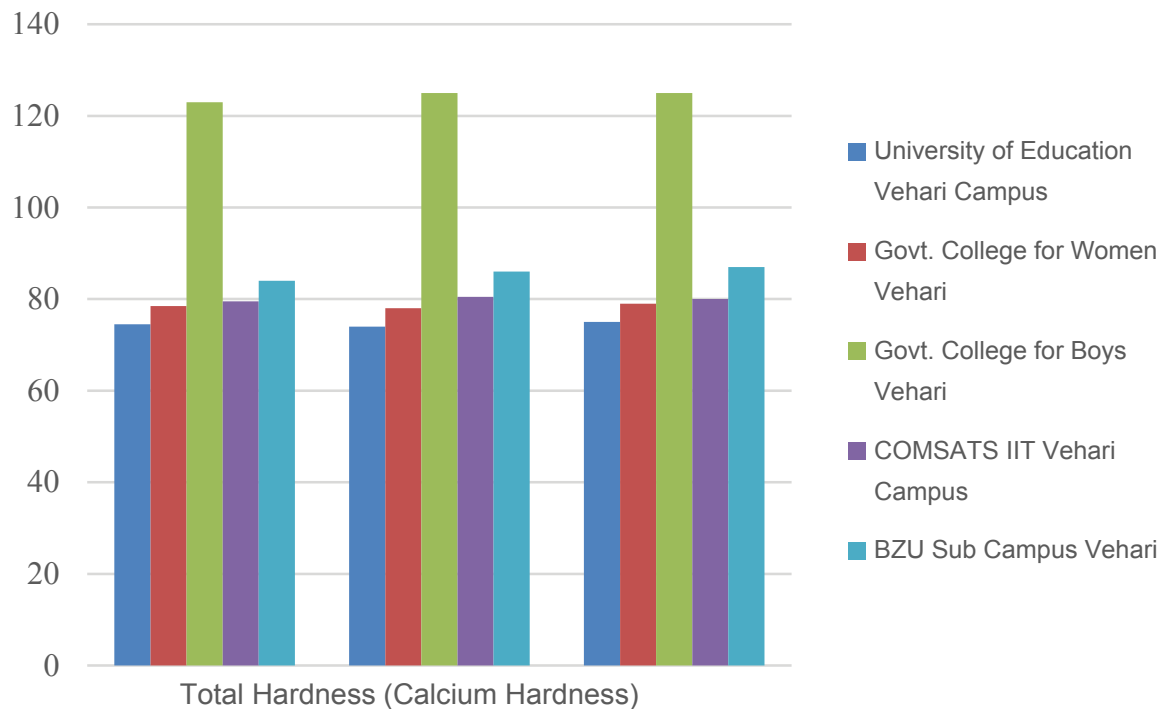

Figure 5: Total hardness (Calcium hardness). 


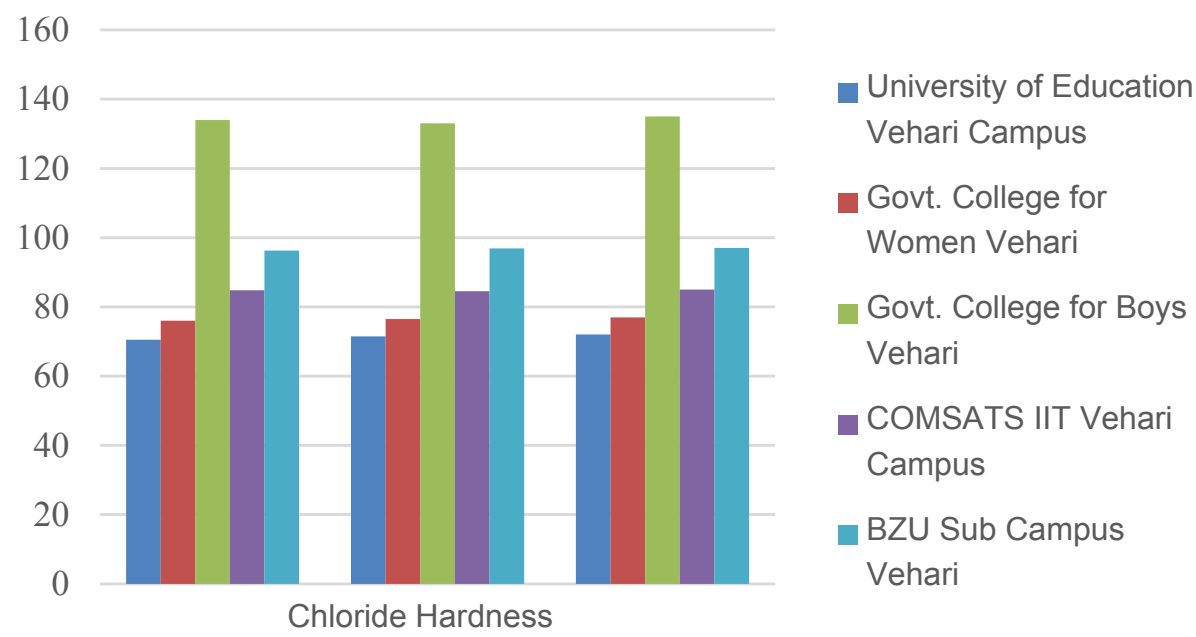

Figure 6: Chloride hardness of all five samples of DW.

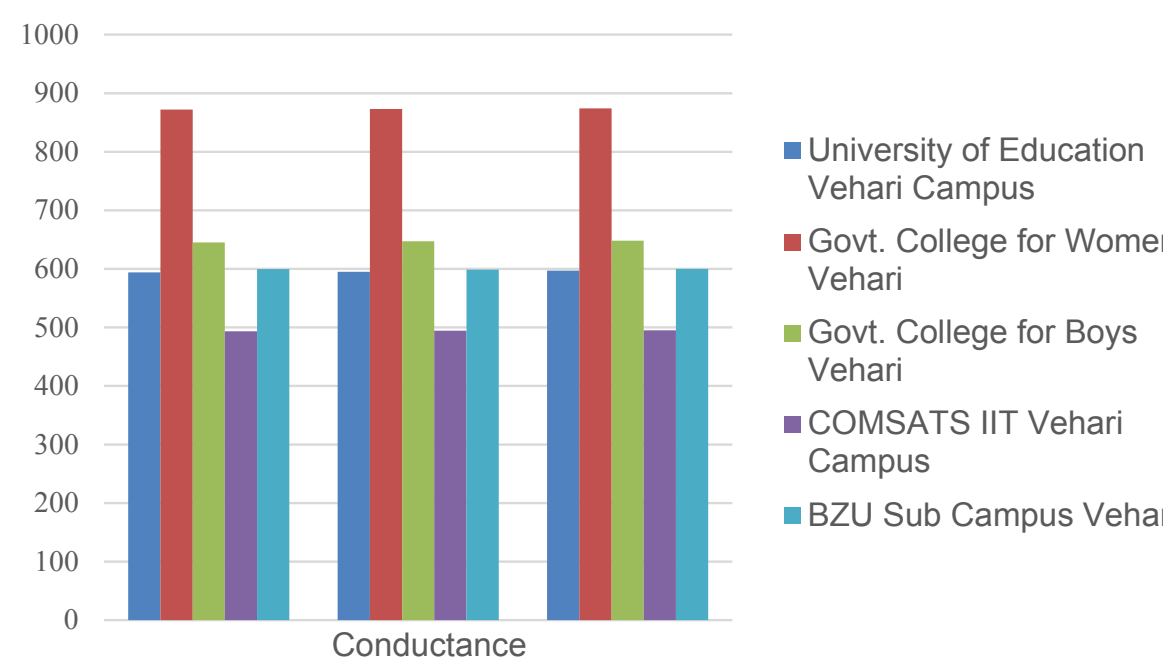

Figure 7: Conductance of all five samples of DW.

\section{Conductivity}

The results of conductivity for all five samples were: Sample- 1 has $597 \mu \mathrm{s} / \mathrm{cm}$, Sample-2 has $874 \mu \mathrm{s} / \mathrm{cm}$, Sample-3 has $648 \mu \mathrm{s} / \mathrm{cm}$, Sample-4 has $495 \mu \mathrm{s} / \mathrm{cm}$, and Sample-5 has $600 \mu \mathrm{s} / \mathrm{cm}$ values of conductance (Table 4; Figure 7).

\section{Conclusion}

The results obtained from the present research work shown that from all five water samples, two water samples are fit for drinking purposes which are Sample-1 and Sample-2, collected from University of Education Vehari Campus and Government College for 0020 Women Vehari, respectively while Sample- 4 and Sample- 5 are moderate hard waters which are not potable. These are collected from COMSATS IIT Vehari Campus and BZU Sub Campus Vehari. The most sever condition containing water sample is Sample-3, collected from Government College for Boys Vehari. Its results show that it is very hard and severely unfit for drinking. It can affect the human health very badly.
So, for Sample-3 and also for Sample-4 and Sample-5, following suggestions are given to coop the water crises.

1. Water should be boiled at right temperature and should be suitable to make sure that it is potable.

2. Clarification of water can be preceded by X-Rays.

3. For high contaminated water, suitable, adjustable and proper chlorination should be done by a chemist because excess of chlorine also severely affect the human health and human body.

\section{Acknowledgements}

The author acknowledges Dr. Muhammad Atif (Assistant Professor, Head of Chemistry Department, University of Education, LahoreVehari Campus, Punjab, Pakistan) for this research study.

\section{References}

1. Khalid A, Malik AH, Waseem A, Shazmeen Z, Murtaza G (2011) Qualitative and quantitative analysis of drinking water samples of different localities in Abbottabad district, Pakistan. 
Citation: M. Fazal-ur-Rehman (2017) Analysis of Quality of Drinking Water Taken from Different Academic Institutes of District Vehari, Pakistan. J Environ Anal Chem 4: 211. doi:10.41722380-2391.1000211

2. Nollet LML (2000) Handbook of Water Analysis. Marcel Dekker, New York, USA, pp: 87-99.

3. Shibukawa M (2004) Characterization and determination of linea alkylbenzenesulfonates in environmental water samples by high performance liquid chromatography with a hydrophilic polymer column and electrospray ionization mass spectrometric detection. Anal Sci 20: 87-91.

4. World Health Organization (2004) WHO Guidelines for drinking - Water quality 3rd edn. Geneva, pp: 3-6.

5. Kodarkar MS (1992) Methodology for water analysis, physico-chemical, Biological and Microbiological Indian Association of Aquatic Biologists Hyderabad Pub 2: 50.
6. Farah N, Zia MA, Khalil-ur-Rehman K, Sheikh MA (2002) Quality characteristics \& treatment of drinking water of Faisalabad city. International Journal of Agriculture \& Biology 4: 347-349.

7. Jaini MH (2003) Determination of Perchlorate in Environmental Waters by Ion Chromatography Coupled with Electrospray Mass Spectrometry (IC-MS) Dionex Application Note, pp: 1-2.

8. Pandey AK, Siddiqi SZ, Rao R (1993) Physico-chemical and biologica characteristics of Husain Sagar, an industrially polluted lake, Hyderabad. Proc Acad Environ Biol 2: 161-167. 